\title{
Getting Them While They're Young: Two Experiences Using Traditional Legal Practice Skills to Interest High School Students in Attending Law School
}

\section{By Angela M. Laughlin ${ }^{1}$}

\section{Angela M. Laughlin is Associate Professor of Law at Texas Tech University School of Law in Lubbock.}

"The legal profession faces no greater challenge in the 21 st century than the critical need to diversify its ranks."

\section{Introduction}

Take a moment and think back to how you first got the idea to become a lawyer. Chances are, your inspiration was someone you knew personally. Now, imagine that your path had never crossed with that of the person who inspired you. This situation is real life for some young people from economically disadvantaged backgrounds: they never have considered a career in law because they rarely encounter such professionals in positive situations.

Law schools need to be creative when it comes to increasing diversity among their student population. Diversity is a compelling state interest ${ }^{3}$ and is important to the legitimacy of legal education

\footnotetext{
${ }^{1}$ Professor Laughlin would like to thank her colleagues for their support and assistance with this article-Assistant Legal Practice Professor Rosemary Dillon, Assistant Legal Practice Professor Kimberley Phillips, Professor Jennifer Bard, Dean Terrence Cook, and Dr. Natalie Turenko.

2 American Bar Associate Conference, November 3-5, 2005, "Embracing the Opportunities for Increasing Diversity in the Legal Profession-Collaborating to Expand the Pipeline (Let's Get Real)," based on a pre-conference report prepared by Diane S. Abraham. The final conference report is available at $<$ www. abanet.org/op /pipelineconf/PipelinePostReport.pdf >. "Increasing Pipeline Opportunities in the Legal Profession for Minorities," Carl G. Cooper, March 2007, of the Metropolitan Corporate Counsel, Northeast Edition, available at <www.metrocorpcounsel.com/current.php ?artType $=$ view\&EntryNo $=6350>$.

${ }^{3}$ Grutter v. Bollinger, 539 U.S. 306 (2003); Gratz v. Bollinger, 539 U.S. 244 (2003); see also Parents Involved in Community Schools v. Seattle School District No. 1, 551 U.S. 127 S. Ct. 2738 (2007).
}

and the legal community. The rate of minority enrollment in institutions of higher learning is decreasing, ${ }^{4}$ and as a result, so are the number of minority students entering law school. ${ }^{5}$ One way that may help to increase minority enrollment is to invest time and resources in the surrounding community. ${ }^{6}$

In February of 2005, at Texas Tech University School of Law, where I teach, the dean of

\footnotetext{
${ }^{4}$ Statistics provided by the Scholastic Aptitude Test (SAT) show that African-Americans, as well as other traditional minority groups such as Hispanic students, score much lower on the SAT than Asian or white students. College Board SAT 2006 College-Bound Seniors, Total Group Profile Report, available at $<$ nces.ed.gov/index. asp $>$. Institute of Education Sciences, United States Department of Education, National Center for Educational Statistics.

${ }^{5}$ According to statistics published by the Law School Data Assembly Service (LSDAS), enrollment is down for all applicant groups. Black/African-American enrollment is down 6.6 percent from 1996, Hispanic/Latino is down 4.2 percent, and Chicano/Mexican-American is down 10.7 percent. Volume Summary Applicants by Ethnic and Gender Group available at LSACnet, $<$ www.1sacnet.org/data/Volume-Summary-Ethnic-Genderapp.htm>. Further ABA data reveals that while non-whites make up 24.9 percent of the country's minorities, they are severely underrepresented in the legal profession. See also ABA statistics of minority demographics in the practice of law.

Minority Demographics

$\begin{array}{lll} & \text { General Population } & \text { Lawyers and Judges } \\ \text { African American } & 12.90 \text { percent } & 4.20 \text { percent } \\ \text { Asian American } & 4.20 \text { percent } & 2.29 \text { percent } \\ \text { Hispanic } & 12.50 \text { percent } & 3.70 \text { percent } \\ \text { Native American } & 1.50 \text { percent } & 0.24 \text { percent }\end{array}$
}

From the ABA Commission on Racial and Ethnic Diversity in the Profession: Goal IX Report 2006-2007, available at <www.abanet.org/minorities/publications/g9/0607goalreport.pdfs. Even by 1971, 17 years after Brown v. Board of Education, total minority enrollment in $\mathrm{ABA}$ law schools was approximately 5 percent. Brief of Amicus Curiae Mass. Sch. of Law at 7, Grutter v. Bollinger, 539 U.S. 306 (2003) (No. 02-241), available at $<$ msl.edu MichiganBrief\%20Amicus.htm>.

${ }^{6}$ See Daniel Golden, Case Study: Schools Find Ways to Achieve Diversity Without Key Tool-State Affirmative-Action Bans Bring Creative Solutions at UCLA, Elsewhere-Critical Race Studies Steps In, Wall St. J., June 20, 2003, at A1; Robert Tomsho, Texas's Race-Neutral Diversity Plan May Face Overhaul, Wall St. J., June 20, 2003, at B1.
¿6 Take a moment and think back to how you first got the idea to become a lawyer. Chances are, your inspiration was someone you knew personally." 
"6 My challenge, more or less, was to introduce these students to the world of law school while not intimidating (or boring) them. ${ }^{9}$
Admissions asked me to help create a program for high school students in our area. One program that the school regularly participates in is the "Groundhog Day Shadow Program." The goal of the "shadow program" is to invite students from our predominately minority high schools to the law school and introduce them to the opportunities available for higher education. We strive to prepare the students for the rigors of higher education by immersing them in the law school environment. My challenge, more or less, was to introduce these students to the world of law school while not intimidating (or boring) them. The students who ultimately participated were chosen from local high schools and magnet programs. ${ }^{7}$

I created two different experiences for these students. My first was a mock-research path that had them searching through the library for answers to legal questions. My second was creating a mockappellate argument where the students chose roles as judges, defense attorneys, or prosecutors. The program was a success. The students overwhelmingly expressed that this was their favorite part of the day. Because we made each student participate, each individual had a different experience. Many of the students realized that they enjoyed the feeling of the judicial robe; they liked putting counsel on the "hot seat." Others found they enjoyed oral arguments more; they had a real talent for speaking in front of groups.

\section{Research Path Exercise}

First, I teamed the high school students with current first-year law students and had the law students guide them through a modified research path. I picked an issue that would be current and perhaps interesting to the high school students: the military draft. While we take it for granted that women do not have to register for the draft, the question that the students needed to answer by the end of the hour and a half was as follows: Why do women not have to register? I decided to use a

\footnotetext{
${ }^{7}$ See Lubbock County Independent School District magnet program, available at <www.lubbockisd.org/Magnet $\rangle$.
}

research path to illustrate what being a "real" lawyer was like, to show that we solve problems and provide a service to others, and to show that being in the courtroom is not all they would be required to do as lawyers.

I started by drafting a scenario, similar to one a firstyear law clerk might face. My ultimate goal in this exercise was to show the students that legal research, while difficult, could be a relevant and rewarding experience. I also talked to the students about a lawyer's role as someone who must answer questions for the client. ${ }^{8}$ After discussing the issue that the client wanted answered, I next had the students brainstorm about different topics that could arise as a result of the question. I also had specific questions I wanted the students to answer at the conclusion of their research.

This exercise gave me the opportunity to show these students how a lawyer goes about answering legal questions. I also emphasized that practicing law is not only about what you know, but more importantly, about being able to find what you do not know. I explained that our next task would be to explore some of the different sources for conducting legal research, including statutes, case law, updating sources, and legal encyclopedias.

I instructed my first-year law students to use this time as an opportunity to answer the students' questions concerning what it means to be a law student, how much time and effort it takes, and how rewarding this experience truly is.

I prepared a grid for the law student helpers to use in assisting the high school students find the necessary information. I had each group start on a different resource, for example, either the United States Code or a legal encyclopedia. I had the law students explain how each resource worked and what kinds of questions each individual resource could answer. I have also contemplated, but not yet incorporated, using Westlaw ${ }^{\circ}$ or LexisNexis, , or even search engines like Google, to show the students the wealth of

\footnotetext{
${ }^{8}$ See Appendix A.
} 
information available on the Internet. During the hour-long exercise, I circulated among the students in the library to answer questions and distribute refreshments (in this case, 1ollipops).

After completing this hands-on exercise, the high school students had a variety of reactions. Some students said they wanted to be lawyers but did not like the "boring research stuff." Other students were excited that they learned about how much work a lawyer actually does and that lawyering is not just about courtroom theatrics. There was positive feedback about the law school and library tours, the interactions with current law students, and the opportunity to see and use the resources of the school and library. The exercise forced the students to actively look for material.

Most important, and one benefit that I had not anticipated, was the educational benefit this exercise gave the volunteering law students. It reinforced what we had discussed in class about research. Also, in teaching the method to others, my students began to appreciate the research process and make the method their own.

\section{Advocacy Exercíse}

On the second occasion I met with high school students, I again pursued an "active" exercise, but this time I kept the students in the courtroom and focused on oral advocacy skills. In preparing for this exercise, I enlisted the help of two other colleagues and gathered a collection of black robes, highlighters, pens, and pads of paper. I adapted an exercise written by Lisa T. McElroy, associate professor of law at Drexel University. ${ }^{9}$ I have subsequently created my own scenario for future programs. $^{10}$

I discovered that I needed to change the legal practice exercise in some significant ways in order

\footnotetext{
9 "cThe Three Bears Redux: It's More Than Just the Facts," available in its entirety at $<$ www.lwionline.org/publications /documents2004/McElroy. Workshop.doc >. See also Randy Lee, Writing the Statement of the Case: The "Bear" Necessities, 10 Whittier L. Rev. 619-635 (1989).

${ }^{10}$ See Appendix B.
}

to tailor it to the level of high school students. First, I wanted to make the scenario more fact-based so that it would be more understandable to the younger audience. Also, I eliminated the references to different jurisdictions and levels of the court.

During the exercise, I broke the students up into three groups: prosecutors, defense attorneys, and judges. I let the students self-select; the groups always turned out evenly disbursed. Each group was facilitated by an individual professor. During their time with each group, the professors would do a quick overview of how the courts work, how appellate arguments work, and the value of case law in decision making. Each professor explained the role of the respective party, explained the cause of action, and helped the students create a short oral argument for the court.

I prepared the students for the role of a judge by first telling them that as judges we had to decide upon the right result. I explained that we needed to review what other courts had done in the past by applying precedent to the situation at hand. Even though we have a lot of knowledge about what happened before, each case is handled individually, and the judge attempts to apply the knowledge gained from prior cases to the case before him or her.

We walked through each of the cases, and I quizzed the students on the facts and the holding of each case, having them explain in their own words what the precedent meant. Next, I asked them, if this was the only available law and based on that case, what should happen in our case? The students brought really interesting insight to the problem. When we used the Goldilocks problem most of the students were adamant Goldilocks should know better than to go into a strange house. Each of them had been taught from an early age not to talk to strangers and never to approach a strange house. Additionally, the students were intrigued by the case law and how precedent shaped the outcome of a case.

I also saw some real diamonds in the rough emerge. Some of the students were shy in the beginning but as soon as they put on a judicial robe, their "inner judge" came out. The student judges were tough on
${ }^{66}$ When we used

the Goldilocks

problem most

of the students

were adamant

Goldilocks should

know better

than to go into a

strange house." 
66 Introducing the students to skills used by lawyers, and getting them active and involved, helped them understand law school in a different way." the advocates, testing the advocate's knowledge of the case law and application. As for the student advocates, they really shone. We saw some talented advocates who truly embraced the exercise. Overall, the students enjoyed the exercise and were excited to go back to high school and describe their experiences.

\section{Conclusion}

These two exercises engaged high school students in the law school experience in different ways than simply attending classes and listening to lectures. Introducing the students to skills used by lawyers, and getting them active and involved, helped them understand law school in a different way. I have done this exercise for three years - each time with great success. We can define success for now in terms of likeability - this is consistently the students' favorite part of the program. We do not yet know how many students may enroll from these schools or how many may pursue a career in the law. One day, I hope I have a student in my class who says, "I remember you from Groundhog Shadow Day and you inspired me to be a lawyer."

\section{Appendix A}

Memorandum

To: Groundhog Job Shadow Day Program Participants

From: Senior Partner

Date: February 4, 2003

Re: John P. Jones Selective Service Question

I received a call this morning from our client, Nathan Jones. Mr. Jones is concerned because his son John is turning 18 next month, and John must register with selective service. $\mathrm{Mr}$. Jones would like to know what the possible consequences are if his son does not register. Mr. Jones would also like to know why his daughter Belinda did not have to register when she turned 18 .

Your research will help me advise Mr. Jones about this issue.

Thank you.
I. Let's start with the first step-set up your pre-search analysis.

1. persons or parties (who):

2. item or subject matter (what):

\section{3. legal concepts:}

\section{Research questions}

1. Why did Congress pass the "Military Selective Services Act"?

2. Who determines the time, place, and manner in which men must register for selective service?

3. What are the possible penalties for failure to register for selective service?

4. Why don't women have to register for selective service?

\section{Guide for Research Facilitators \\ Group 1}

Using the United States Code Annotated ${ }^{\circ}\left(\mathrm{USCA}^{\circ}\right)$ index, look up selective service; it will refer you to "Military Selective Service" (50 U.S.C.A. app. $\$ 451$ et seq.).

Section 451 is Congress' declaration of policy - it explains why this Act was passed.

Section 453 states that all men between 18 and 26 must register. It also gives the president the authority to name the time, place, and manner of registration.

Section 462 talks about offenses and penalties.

When you examine the USCA annotations for section 453, which sets out the registration requirements of the Military Selective Service Act, you will see a note that covers "Exemption of Women." This note references the case Rostker $v$. Goldberg. 
Move to the Federal Practice Digest ${ }^{\circ}$. Look up the lower court opinion in Rostker v. Goldberg.

Since the USCA only gives you the Supreme Court case, look up the case name in the Table of Cases.

This is a good opportunity to talk about how you can find cases using the Federal Practice Digest. You will get a lot of information from the Table of Cases, including some indication of how the Supreme Court treated this case.

Look up the U.S. district court case at 509 F. Supp. 586.

Talk about the "anatomy" of the opinion. What are all the parts? Talk about the holding - here the statute was found unconstitutional.

You can talk about levels of government herewhere a district court fits into the larger federal court scheme, or about constitutional law-how can a court tell Congress that a statute is unconstitutional?

Headnote 15 discusses the court's reasoning for its decision.

Help them answer the questions for the client.

\section{Guide for Research Facilitators}

\section{Group 2}

Using the American Jurisprudence $2 d$ General Index, look up Selective Service-Military Services-Conscription

Volume $53 \$$ Military and Civil Defense 90 Registration-Military 90-93

\section{Refusal-156-157}

Section 90 will address each of the four research questions posed by the assigning attorney.

Footnote 76 references the Supreme Court case Rostker v. Goldberg, 453 U.S. 57, 101 S.Ct. 2646, 69 L.Ed. 2d 478 (1981).

Go ahead and look up the Supreme Court case-use as an opportunity to talk about the anatomy of a case.

Help the Groundhog Shadow Day participants answer the questions for the client.

\section{Appendix B}

General Information for All Students

Facts: State of Enchantment v. Hunter

Mr. Peter Hunter was convicted of second degree murder by a jury in the district court. Hunter was charged in the death of John "Big Bad" Wolfe. The state prosecuted Mr. Hunter after John Wolfe was discovered dead in a nearby forest. Mr. Hunter swears that he was protecting a young girl, Little Red Riding Hood. According to Mr. Hunter, Mr. Wolfe had followed Ms. Hood into the forest, attacked Hood's grandmother, and attempted to abduct Ms. Hood.

Ms. Hood testified at trial that she was walking through the woods to deliver food to her sick grandmother. A stranger, identified as Mr. Wolfe, approached her, and she naively told him where she was going. Mr. Wolfe then suggested that Ms. Hood pick the nearby flowers for her grandmother, which she did. When Ms. Hood arrived at her grandmother's house, a wolf answered the door dressed in women's clothes. Ms. Hood became frightened and ran deeper into the woods.

Mr. Hunter, who was chopping wood nearby, heard the screams of Ms. Hood and ran to her. Upon meeting up with Mr. Hunter, Ms. Hood explained what had happened. Suddenly, John Wolfe showed up on the scene, out of breath from running. Before Mr. Wolfe could even speak, Mr. Hunter struck him with the axe.

According to the testimony of the grandmother, it was not Mr. Wolfe who entered her house on that day. In fact, it was Mr. Wolfe's cousin, Alfred "Pig Snatcher" Wolfe, who was the culprit. The grandmother was able to pick out Alfred from a lineup. It turns out Alfred was out on bail, as he had recently been arrested on another breaking and entering charge involving three pigs.

Mr. Hunter is appealing his conviction, and he argues that the lower court judge did not allow him to present a defense of justifiable homicide. 
The law in the State of Enchantment is that justifiable homicide is divided into two situations: (a) homicide owing to an unavoidable necessity, and (b) homicide committed for the prevention of some atrocious crime which cannot otherwise be avoided. If a defendant proves the act was justified, there is no penalty, either by way of fine or imprisonment.

In justifiable homicide cases the important issue is the proportional response to the threatened evil. That is, only an action against a person that seems to put someone in imminent danger of death allows us to repel that action with death.

Here are the major cases cited in the parties' briefs:

State of Enchantment v. Prince Charming. Prince Charming was charged and convicted in the slaying death of the Wicked Witch. Prince Charming argued at trial that he was defending Snow White, who was in imminent danger. The prosecution argued that Prince Charming was never in danger nor did he ever perceive he was in danger. The court of appeals overturned the guilty verdict saying that the lower court should have applied the alter ego rule. The appellate court stated, "The court must not view the actions from the point of view of the defendant, but instead, take the point of view of the person he was seeking to defend."

State of Enchantment v. John Pig. John Pig was convicted of murder in the shooting death of the Big Bad Wolf. The lower court denied Pig's request for a justifiable homicide instruction because the court found that Pig did not have an "actual and reasonable" belief that he must protect another from imminent danger of death or great bodily harm. The court held that under the alter ego rule, one who attempts to defend another person steps into the shoes of the other person, and so acts at his own peril if that person was in the wrong. The facts adduced at trial suggested that Pig's brother Tom and Big Bad Wolf were not arguing, but instead, were practicing for a debate at school the next day.
State of Enchantment $v$. Jack. Jack went up a hill to fetch a pail of water and on the way back down met up with his cousin, Jill. As he and Jill entered the forest, a man attacked Jill. Jack was able to save Jill by beating up the attacker. The court in its opinion said that the justifiable homicide instruction had never been extended to the cousin relationship. However, while the defense typically had only been allowed with husband and wife, parent and child, or brother and sister, the court extended it to cover this situation. The court of appeals affirmed.

State of Enchantment v. Peter "Pumpkin" Eater. The lower court refused to instruct the jury on the defense of justifiable homicide. Here the decedent snatched a piece of pie from Mrs. Eater. Peter killed the man with a knife. The court said "... that a person may lawfully do in another's defense what such other might lawfully do in her own defense, but no more." Although a victim had the right to use reasonable force to recover her property, the act in question here, killing the thief, was not apparently reasonably necessary.

State of Enchantment $v$. Cinderella. The court affirmed the conviction of Cinderella for the murder of her stepsister. The lower court had properly instructed the jury with regard to the defense of justifiable homicide. While traveling to the ball, Cinderella's carriage was taken over by her angry stepsister. The lower court found insufficient evidence that Cinderella ever perceived that she was in imminent physical danger. The court based this finding on the lack of physical strength of the stepsister and the lack of any visible weapon.

(c) 2008 Angela M. Laughlin 